\title{
ARCHAEOLOGY IN GREECE 2015-2016 Habitation in the region of Mount Ossa during the Early Byzantine period
}

\author{
Stavroula Sdrolia | Ephorate of Antiquities of Larisa | ssdrolia@culture.gr
}

Archaeological works undertaken in the last decade - excavation, survey and conservation - prompted by major public works, combined with synthetic studies, have enhanced our knowledge of Thessaly in the Byzantine period. Key areas where our understanding has increased significantly include urban and rural fortifications, the Late Antique phases of occupation in Larisa and the harbour at Phthiotic Thebes (modern Nea Anchialos), religious and secular architecture, rural villas, industrial installations and the monastic community on Mount Ossa ('Mountain of the Cells').

This paper focuses on the region of Mount Ossa (later Kissavos), where the data resulting from recent investigations have revealed a vibrant Late Antique phase, characterized by dense habitation on the slopes of the mountain (Map 9). Mount Ossa, on the eastern side of the narrow Tempe valley, lies in an advantageous location since it is situated at the crossroads of major routes: to the west is the main north-south land route connecting southern Greece to Macedonia and the north; to the east, on the Aegean shore, is the alter-

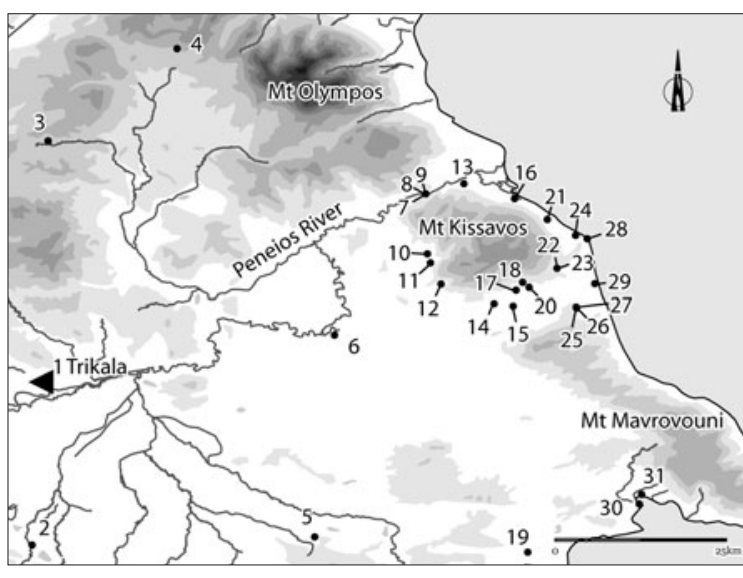

Map 9. Sites mentioned in the text. (C) BSA. 1 Trikala; 2 Kallithero; 3 Kastri-Loutro; 4 Kastri Doliches; 5 Pharsala; 6 Larisa; 7 Chani tis Kokonas; 8 Chrapes; 9 Tsiriga Chorafia; 10 Pournari; 11 Sykourio; 12 Marmarine; 13 Omolio; 14 Gerakari; 15 Aetolophos; 16 Stomio; 17 Neromyloi; 18 Metaxochori; 19 Phthiotic Thebes (Nea Anchialos); 20 Agia; 21 Kokkino Nero; 22 Velika; 23 Koutsoupia; 24 Paliouria; 25 Skete; 26 Kastri Agias; 27 Agiokambos; 28 Cape Dermatas; 29 Kato Sotiritsa; 30 Demetrias; 31 Volos. native coastal road that offered access to southern Greece when the Tempe pass was closed; and to the south, is the road that linked the city of Larisa with the Aegean sea. The landscape of the region, which is characterized by well-irrigated, fertile, low-lying slopes, favoured the formation of numerous ancient settlements.

During the Early Byzantine period, Tempe was still the major pass in and out of Thessaly. Rescue excavations in the Tempe region have yielded new finds, which are significant for understanding the

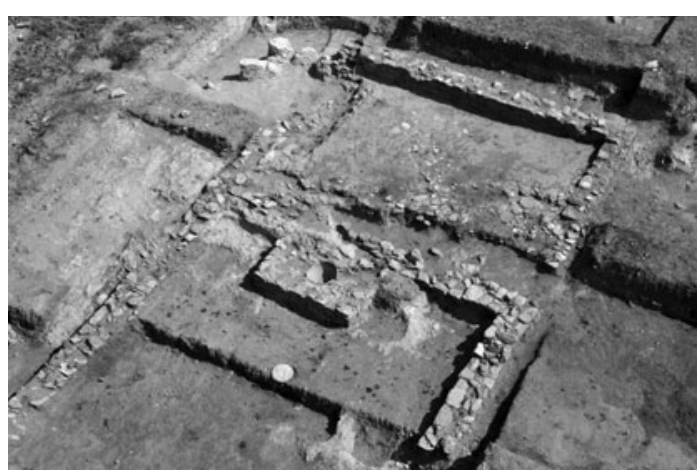

98. Tsiriga Chorafia, near Tempe: wine press.

(C) Hellenic Ministry of Culture and Sports: Ephorate of Antiquities of Larisa. diachronic importance of the pass and the cults and economy of the region from the Classical to the Late Byzantine period. These finds are associated with an unidentified settlement, the development of which was linked to the operation of a large white-marble quarry, located at the locality of Chrapes (ID1357; Melfos et al. 2010: 850-51).

In 2008 investigations began in part of a cemetery that was revelaed during construction of a new stretch of the E75 road at the western exit of the pass, at the locality of Tsiriga Chorafia (ID4725). The cemetery consisted of cist graves which have been dated on numismatic evidence to two periods: the fourth and the sixth century AD. Also discovered at this site were a wine press with 
a pithos storage area (Fig. 98), a lime kiln, a pottery kiln and poorly preserved remains of domestic architecture suggestive of the existence of a settlement that must have extended onto the verdant slopes of Mount Kissavos. A coin hoard, dated to the fourth century AD, was discovered among the ruins of the settlement, and this supports the hypothesis that it was destroyed during Alaric's attacks in AD 396; the site was occupied again during Justinian's reign (Sdrolia 2009: 585-86). This area is adjacent to the the locality Chani tis Kokonas, a site with continuous habitation from the Hellenistic period onwards, where recent rescue excavations revealed a Byzantine church, which succeeded an ancient temple, and a Byzantine inn (ID2328; AR 58 [2011-2012]: 86-88).

Because of its strategic importance, the Tempe pass was already protected in the first millennium BC by a fort erected at the narrowest point of the valley. Although a Late Antique phase is no longer visible among the Byzantine remains of the so-called Kastro tis Orias, its existence is confirmed by references in the works of 19th- and early 20th-century scholars (Theodoropoulos 2010a: 24-25).

At the northeastern exit of the Tempe pass, a surface survey, conducted in association with the construction of the E75 road tunnel, revealed Early Byzantine remains at the site of Paliokklesi, near the tunnel exit. These included the remains of a church, that was visible until recently, and next to it remains of a settlement dating to Late Antiquity, as well as a few associated graves, which are still visible today. The site, below which Apostolos Arvanitopoulos saw remains of baths and inns in 1911 (Arvanitopoulos 1911: 289-91), is linked to the control of the entrance to the Tempe pass and the nearby bridge over the river Peneios; it is also related to the ancient Sanctuary of Apollo, which was later succeeded by a Christian shrine (Sdrolia 2009: 587).

Alongside investigations in the Tempe valley, research and excavations in recent years have facilitated a far better understanding of the dense settlement in the Early Byzantine period in the coastal zone of Mount Kissavos, both fortified and unfortified (Drakoulis 2010: 381-83; Sdrolia 2014). Among the forts situated in the eastern coastal region of Thessaly, the first one north of the Tempe pass is located at Kastri-Loutro; it was recently dated to the seventh to eighth century AD (Papathanassiou 2010: 292-93). There are more settlements along the coastal route on the eastern side of Mount Kissavos, some of which succeeded ancient Magnesian towns (Nikolaou and Kravaritou 2012). Specifically, there is evidence of eight settlements in the area stretching from Omolio in the north to Agiokambos in the south. Starting from the area of Omolio and Stomio, where there are scattered finds but no architectural remains of the settlements of the Early Byzantine period (Sdrolia 2014: 61-63), the first site noted is at Kokkino Nero, which, according to current scholarly views, can be identified with the ancient city of Eurumenai (for a summary of the scholarship, see Nikolaou and Kravaritou 2012: 201-04; contra Helly 2013: 175). There are strong fortifications at Kokkino Nero, on a steep slope that rises abruptly from the sea, north of the village (Fig. 99); these command the entire northeastern coast of Mount Kissavos, from Stomio to Cape Dermatas. Following clearing operations conducted recently by the Department of Antiquities of Larisa, part of the southern face of the wall of the acropolis is now visible; the wall was built with small and medium-sized stones and strong mortar, and is dated to the Early Byzantine period. Ancient pottery is plentiful in the rich fill that covers the acropolis hill, while the upper layer of the fill dates to the Middle Byzantine period (Sdrolia 2014: 63-65). In the area of the villages of Koutsoupia and Paliouria there is evidence suggestive of Early Byzantine habitation; a harbour installation was recently identified at Koutsoupia (ID3134; Sdrolia 2014: 65). In the area south of Cape Dermatas, the fortress of Velika, situated on a small hill north of the modern settlement, ca. 500m from the sea, commands the coast of Mount Kissavos and Mount Mavrovouni as far as Mount Pelion, and the sea route from the Pagasetic to the Thermaic Gulf and the Chalkidike peninsula. In the fertile plain south of Velika, sporadic finds attest to the existence of another two coastal settlements of the Early Byzantine period at Kato Sotiritsa and Agiokambos (Sdrolia 2014: 68-70).

The most important among the settlements mentioned above are those at Kokkino Nero and Velika, both because of their favourable geographical locations and the strong fortifications they preserve. Here we should locate the settlements of Eurumenai and Kentauropolis, respectively. These are mentioned by Procopius, who informs us that Justinian ordered the construction of their walls. The reasons for the identification of the settlement at Velika with Kentauropolis (the latter was until recently identified with the 


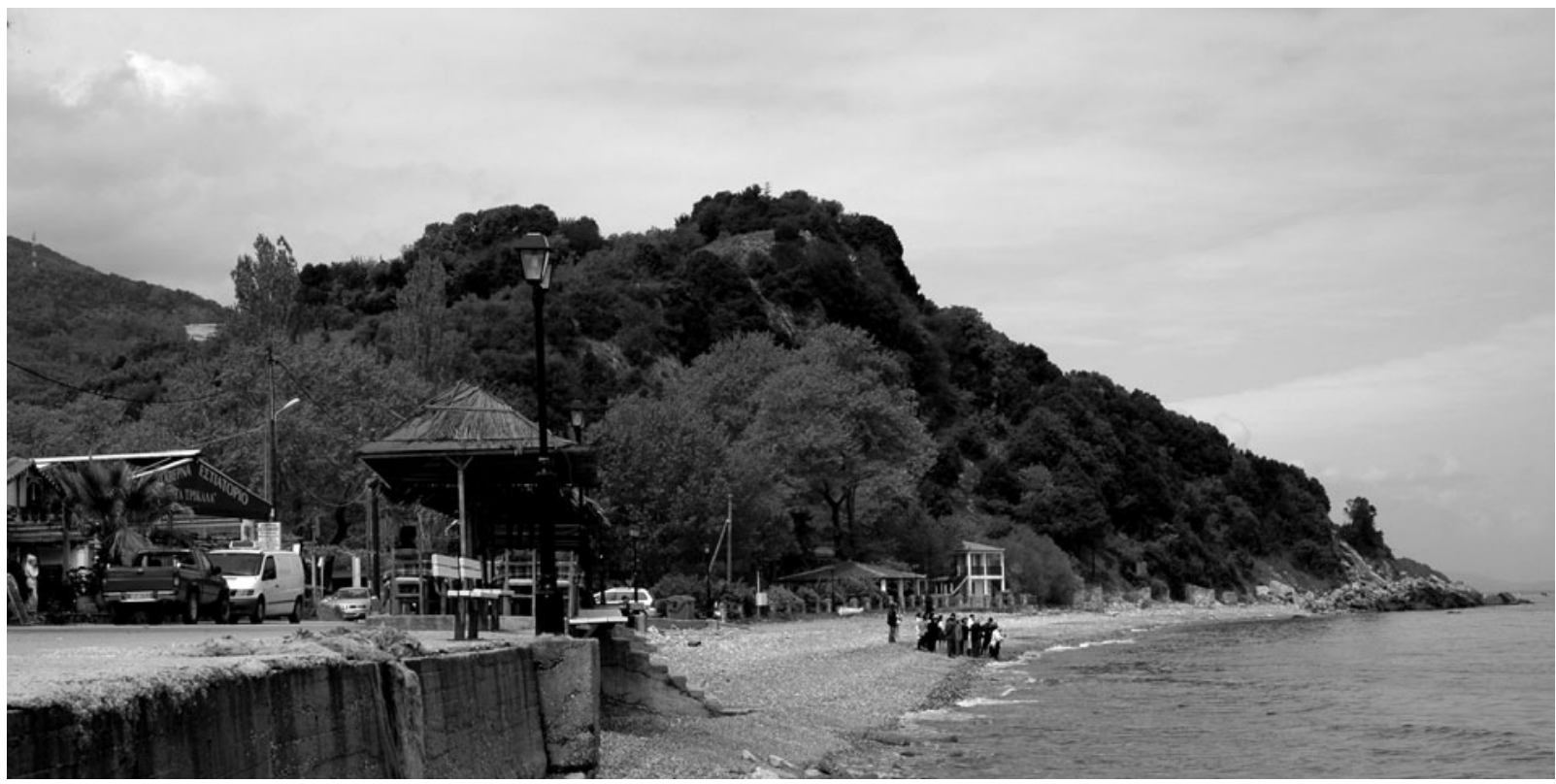

99. Kokkino Nero: fortifications. (C) Hellenic Ministry of Culture and Sports: Ephorate of Antiquities of Larisa.

remains at Skete: see Koder and Hild 1976: 186-87) are the large number of finds dating to the Early Byzantine period (which do not exist at Skete), the strong similarity of the fortress of Velika to that at Kokkino Nero (ancient Eurumenai, the fortification of which is mentioned together with that of Kentauropolis by Procopius) and Procopius' indication that these two fortresses succeeded ancient cities and that the reorganization of the defence of Thessaly was a policy of Justinian.

The most informative data about life in the coastal settlements of Mount Kissavos during the Early Byzantine period were collected during the excavations at the fortress of Velika, which was first discovered in 2008 (ID1356, ID2027, ID2327, ID4747, ID5228; Sdrolia 2009; 2013a, 2014; Vlazaki 2012; Gerousi 2013). The fortified settlement of the Early Byzantine period (2.1 ha) made use of the ancient fortifications at the site, which were partially preserved in the southern and eastern sections. The existence of these ancient fortifications and references in ancient sources plausibly support the identification of the site with the ancient city of Meliboia, the most famous Magnesian city in the region; Meliboia was

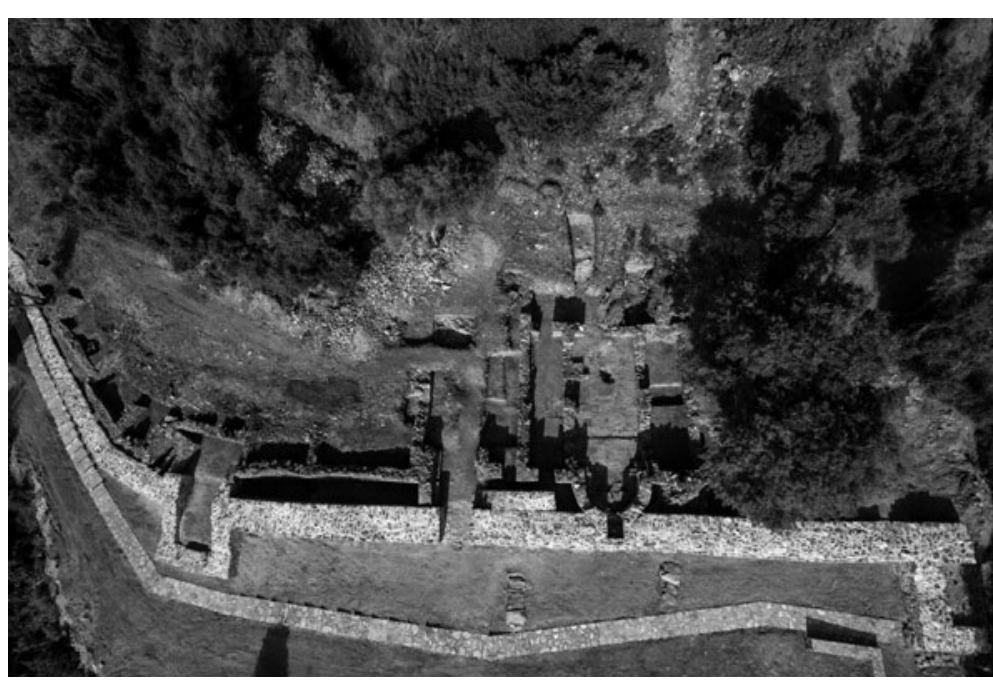

100. Velika: fortifications (2013). (C) Hellenic Ministry of Culture and Sports: Ephorate of Antiquities of Larisa. destroyed by the Romans in $148 \mathrm{BC}$ and was apparently later renamed Kentauropolis by Justinian.

Restoration works funded by the European Union's National Strategic Reference Framework (Е $\Sigma \Pi A)$ offered the opportunity to investigate the site and clarify the plan the fortifications - in relation in particular to the gates and towers, and the staircases that allow access to the walls the construction methods and the successive phases of reinforcement. At the same time, numerous buildings were revealed along the inner eastern and southern faces of the fortifications. These include guardrooms, storerooms (ID2327), a 
house and a three-aisle basilica (ID4747, ID5228) (Fig. 100). The latter was investigated as part of a fiveyear collaborative project directed by the University of Thessaly and the Ephorate of Antiquities of Larisa, co-directed by Ioannis Varalis (AR 59 [2012-2013] 110; AR 61 [2014-2015] 27).

The three-aisle basilica with a wide narthex is part of a complex that includes outbuildings as well as a cemetery. It dominates the northeastern part of the fortress, along with a house on the southern side which stands very near the main gate located at the southeastern corner of the fortress (Fig. 101). The house is organized as three wings around a central courtyard and must be related to the presence of an official who was in charge of the movement of agricultural produce in the area, as demonstrated by the central position of the house and its important finds.



101. Velika: the house and/or gate on the southern side of the fortifications. (C) Hellenic Ministry of Culture and Sports: Ephorate of Antiquities of Larisa.

Habitation at Velika extended outside the fortification walls, as is revealed by an ecclesiastical complex with an olive press and warehouses that was excavated on the eastern slopes of the hill towards the beach (ID2027; Sdrolia 2009: 587-88). We should infer the existence in this area of harbour installations, which have been covered by the alluvial deposits of the Dragoutis stream.

The fortification at Velika is a strong construction; its walls are $2 \mathrm{~m}$ wide, built with rough stones and strong lime mortar. It has been dated on numismatic and other evidence to Justinian's reign. To this day, these are the best-investigated fortifications of this period in Thessaly, despite the fact that half the enceinte is still covered by vegetation. The abandonment of the settlement after the seventh century AD contributed to the good preservation of the Early Byzantine layers, which contain large numbers of pottery, glass and metal finds. The pottery, in particular, includes many imports from various centres. The wide variety of storage and transport vessels (in particular amphorae of the Late Roman 2 type) attests to the commercial links this settlement had developed with distant centres and shows that it participated in the commercial network of the Aegean. Imported lamps from Africa and plates from Nea Anchialos (Central Greek Painted Ware), as well as from Africa and Asia Minor, are indicative of the trade links of the region. The significant 
quantities of pithoi and especially of transport amphorae link Velika to other small commercial centres in the Aegean. The agricultural produce of the region was distributed via sea routes, and was under state control through the annona militaris; the small coastal forts must have been part of this network (Karagiorgou 1999).

The complex network of sea routes in this part of the Aegean and the harbour installations of coastal Thessaly which supported it during Byzantine times recently formed the focus of a systematic study that included underwater investigations conducted under the auspices of the EMA (Ginalis 2014). This research project highlighted the important role of the harbours of the Pagasetic Gulf and Skiathos (ID2905) on the sea route that connected Thessaly, Constantinople and the Black Sea (AR 58 [2011-2012] 92). The region of Velika was part of this network; already in antiquity (definitely by the Hellenistic period, but possibly even earlier) it was linked both with Demetrias and the Chalkidiki peninsula and the Thermaic Gulf. Evidently, the major harbour of Thessaly during Late Antiquity was that of Phthiotic Thebes (modern Nea Anchialos), where in recent years important building remains have been discovered (ID1081-1089, ID2029, ID3949, ID3955-3957, ID3967, ID4722-4723; Dina 2006).

An important industrial installation with pottery kilns was discovered at Kato Sotiritsa (Sdrolia 2014: $69), 5 \mathrm{~km}$ south of the fortress of Velika. The discovery of roof tiles in situ in the excavated part of the workshop show that it produced building materials (Fig. 102). The size of the installation does not preclude it having served the needs of the settlement at Velika; this hypothesis needs to be tested through future investigations in the area. There must have been a settlement of the Early Byzantine period in the area of Sotiritsa. This is clear from the extensive evidence for habitation, including ecclesiastical buildings, secular buildings and a cemetery. The same can be presumed for Agiokambos, where architectural members belonging to a church, building

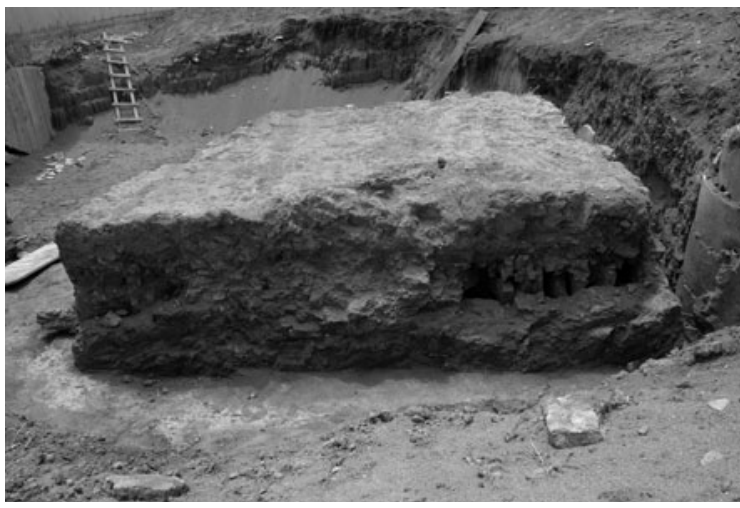

102. Kato Sotiritsa: tile kiln. (C) Hellenic Ministry of Culture and Sports: Ephorate of Antiquities of Larisa. remains and pottery have been discovered.

A recent study of settlement patterns in the region has shown that smaller settlements were organized around the regional centres of Eurumenai and Kentauropolis (Drakoulis 2010, although he does not place the latter at Velika). Evidence for a hierarchy among rural settlements exists for other regions, such as Macedonia (Dunn 2004), where the distances between settlements range from $3 \mathrm{~km}$ to $5 \mathrm{~km}$, similar to those known in Thessaly.

Research on habitation on the southern and western slopes of Mount Kissavos remains in its early stages. Nevertheless, it is evident that the fertile basin of Agia, between Mount Kissavos and Mount Maurovouni, was guarded on the east by the large fortress at Skete. The numerous Late Antique architectural and funerary reliefs in the archaeological collection of Agia imply the existence of a flourishing contemporary settlement in the area between Agia, Metaxochori and Neromyloi (Sythiakaki 2012). An ancient city had existed in the same area, as is evident from the ancient acropolis and Roman baths at Neromyloi (Helly 2013: 287). Habitation later moved east, towards Agia, and west, towards the Byzantine city of Vesaina (the modern settlements of Vathyrema and Aetolophos: Drosos 2013). Further west at Gerakari, Early Byzantine remains have been excavated, among them part of a bath complex (ADelt 52 [1997] Chr. 541-42). The western entrance to the valley, through which Larisa was connected to the sea, was guarded during the Early Byzantine period by two important fortresses: at Kastri (Koder and Hild 1973) and Marmarine. The location of the latter on a steep slope of Mount Kissavos, appropriate for controlling the narrow, lakeside road to the south, makes it unlikely that there had been a settlement inside the fort (Theodoropoulos 2010b: 153). We should place the Late Antique settlement closer to the modern village of Marmarine, where many contemporary architectural remains have been found and where, in 
later times, the largest monastery of the metropolis of Larisa, that of Agios Demetrios Marmarianon, was established (Drosos 2013: 307-11). The importance of the region on the southwestern slopes of Mount Kissavos is further underlined by the existence of a quarry for the famous verde antico at a site close to and west of Marmarine (Melfos 2009); the quarry was intensively exploited during Justinian's reign.

At neighbouring Sykourio, an Early Christian

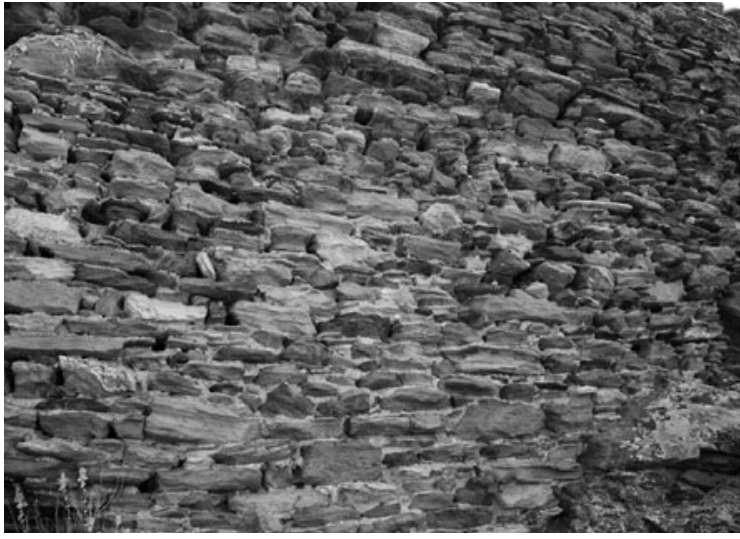

103. Pournari: fortifications. (C) Hellenic Ministry of Culture and Sports: Ephorate of Antiquities of Larisa. offering slab, dated to the fifth century $\mathrm{AD}$, is evidence for the existence of a martyrio, a monument dedicated to the Early Christian martyrs (Lazaridou 2012: 130, no. 89). Further north, above the settlement at Pournari, a strong fortification extending over a large area has been revealed (Fig. 103), and it seems to have contained a Late Antique settlement (Theodoropoulos 2010b: 154-57). This site could have controlled the fertile basin of Sykourio and the passage to southern Greece for those coming from Tempe and wanting to bypass Larisa.

To sum up, the sites mentioned above reveal the existence of an important network of settlements along the slopes of Mount Kissavos during the Early Byzantine period, around which major communication routes radiated both on land and sea. The fertility of the region, the cultivation of produce for export (such as olive oil and wine), the local availability of primary materials, such as marble, and the presence of harbour installations led to the area's development, extending the life of its ancient cities. This impression is reinforced by the existence of strong fortifications, which were situated at strategic locations, selected as the most important sites within this dense settlement network to enable command of a large area. The existence of an ancient acropolis does not seem to have been a definitive reason to include a site in this fortification network; in fact, the defence network of the Early Byzantine period seems to have been designed anew. The same is true for the succeeding period, when some of these fortresses were abandoned and others were reused. The Early Byzantine settlement network along the land route and the distance of $10-15 \mathrm{~km}$ between major fortresses implies that its creation was part of a unified design that was implemented by a strong central authority. At present, only the fortress at Velika can be dated securely on excavation data to Justinian's reign; on comparative grounds, though, it seems that the fortress at Kokkino Nero also dates to the same period. Similarities in construction suggest that the other forts must be roughly contemporary. Their most characteristic feature is construction with medium-size stones and strong lime mortar without the presence of tiles.

These data on the Early Byzantine fortifications on Mount Ossa can be compared to the evidence collected during recent investigations of city fortifications of the same period, such as that from Larisa (ID1080, ID4727; Sdrolia 2006; Kontogiannopoulou 2009), Trikala (Mantzana and Vlahava 2014), Pharsala (Katakouta and Gialouri 2014), Volos (ID3959, ID4721; Anastasiadou and Dina 2014) and Phthiotic Thebes (ID3949, ID4722; Karagiorgou 2013: 159). In all these examples there is evidence of attention having been paid to the fortifications of the period under study, but the most useful results are those gained from investigations of the fortifications of Larisa, where no other phases exist. In recent years, fortifications of the Early Byzantine period have been investigated at other regional centres in Thessaly that controlled important routes, such as Kastri Doliches (ID1055, ID1056, ID3974, ID4726; Deriziotis and Kougioumtzoglou 2006) and Kallithero (ADelt 53 [1998] Chr. 440-42). The considerable investment in fortifications during the Early Byzantine period is evident, and reveals the importance given to the defence of the coastal route and of Thessaly as a whole. The recent finds have allowed a better understanding of Justinian's policy towards the countryside and its defence. The power and involvement of the central imperial authority in Thessaly is evident, as also is the threat from imminent dangers, which resulted in a frantic effort to fortify cities and the countryside. 
Most of the fortresses in the area of Mount Kissavos were gradually abandoned in the course of the seventh century AD; their inhabitants moved to other settlements, often away from the sea. In the following centuries the eastern slopes of Mount Kissavos were used by hermits and monks; in the $11^{\text {th }}$ and $12^{\text {th }}$ centuries monastic life in the area flourished, giving the region the name Oros ton Kellion (Mountain of the Cells: ID2000; Sdrolia 2013b).

Archaeological activity over the last decade has demonstrated that the Early Byzantine period in Thessaly was vibrant, with key sites receiving considerable investment from the central authority. At present, the absence of systematic studies does not permit further observations about the appearance and layout of settlements or relations between them. However, this brief overview has hopefully shown how promising further study would be, especially of the secular and ecclesiastical architecture of this period, fortification systems, trade links and agricultural exploitation of the land.

\section{Bibliography}

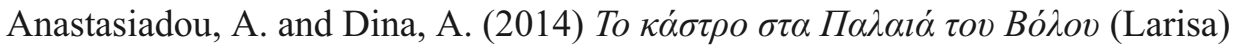

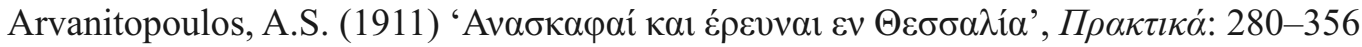

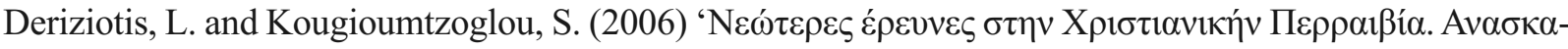

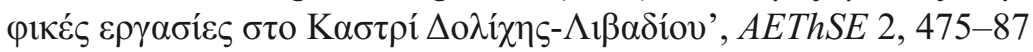

Dina, A. (2006) 'П AEThSE 2, 423-39

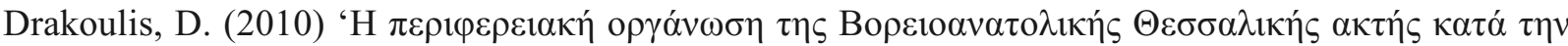

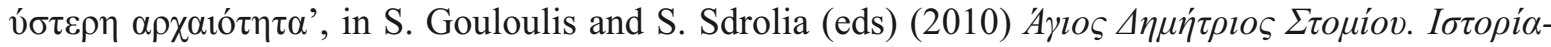

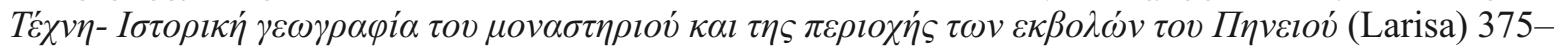
90

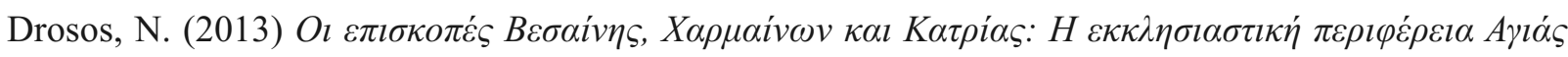
$\kappa \alpha \tau \alpha \dot{\alpha} \tau \eta \beta v \zeta \alpha v \tau \imath v \dot{\eta} \kappa \alpha \imath \mu \varepsilon \tau \alpha \beta v \zeta \alpha v \tau \imath v \eta \dot{~ \pi \varepsilon \rho i o \delta o . ~ P h D ~ t h e s i s, ~ U n i v e r s i t y ~ o f ~ T h e s s a l o n i k i ~}$

Dunn, A. (2004) 'Continuity and change in the Macedonian countryside from Galienos to Justinian', in W. Bowden, L. Lavan and M. Machado (eds), Recent Research on the Late Antique Countryside (Leiden and Boston) 533-86

Gerousi, E. (2013) 'Rural Greece in the Byzantine period in the light of new archaeological evidence', in J. Albani and E. Chalkia (eds), Heaven and Earth, Cities and Countryside in Byzantine Greece (Athens) $31-43$

Ginalis, A. (2014) Byzantine Ports: Central Greece as a Link Between the Mediterranean and the Black Sea. DPhil Thesis, University of Oxford

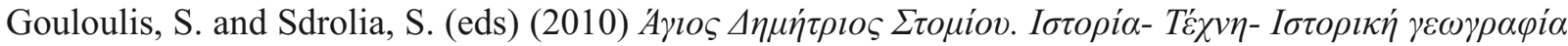

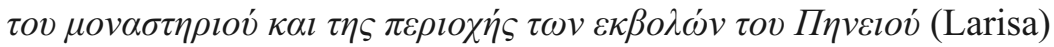

Helly, B. (2013) Géographie et histoire des Magnètes de Thessalie (Vareilles)

Karagiorgou, O. (1999) 'LR2: a container for the military annona on the Danubian border?', in S. Kingsley and M. Decker (eds), Economy and Exchange in the East Mediterranean During Late Antiquity, Proceedings of a Conference at Somerville College, Oxford (Oxford) 129-66

- (2013) 'Christian or Thessalian Thebes: the port city of Late Antique Thessaly', in J. Albani and E. Chalkia (eds), Heaven and Earth, Cities and Countryside in Byzantine Greece (Athens) 156-67

Katakouta, S. and Gialouri, A. (2014) $\Phi \alpha ́ \rho \sigma \alpha \lambda \alpha$ (Larisa)

Koder, J. and Hild, F. (1976) Hellas und Thessalia (Tabula imperii byzantini 1) (Vienna)

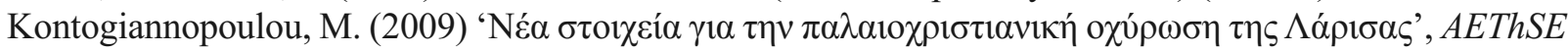
3, 671-76

Lazaridou, A. (ed.) (2012) Transition to Christianity. Art of Late Antiquity, $3^{\text {rd }}-7^{\text {th }}$ Century AD. Catalogue of Exhibition Held at the Onassis Cultural Center. New York City, December 7, 2011-May 14, 2012 (New York)

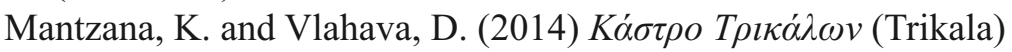

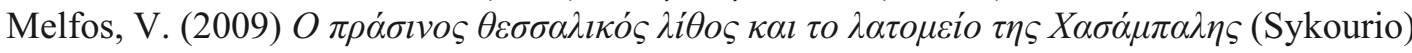


Melfos, V., Voudouris, P., Papadopoulou, L., Sdrolia, S., Helly, B. (2010) 'Mineralogical, petrographic and stable isotopic study of ancient white marble quarries in Thessaly, Greece II. Chasanbali, Tempi, Atrax, Tisaion mountain', Bulletin of the Geological Society of Greece, Proceedings of the $12^{\text {th }}$ International Congress, Patras 43.2, 845-55

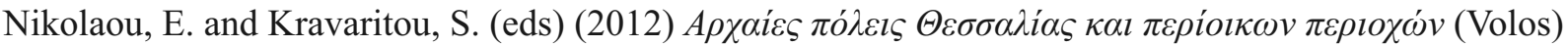

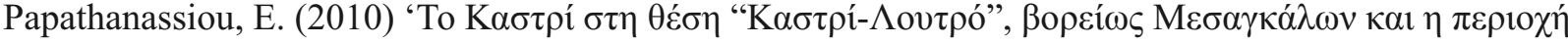

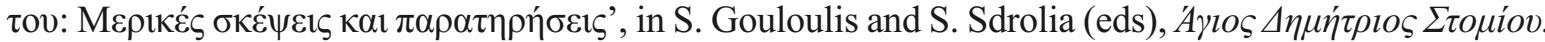

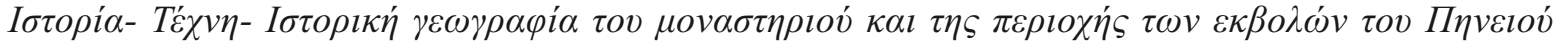
(Larisa) 273-314

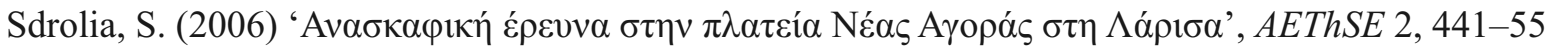

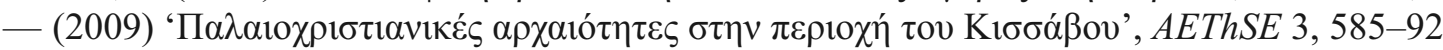

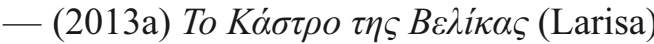

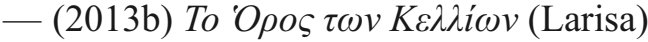

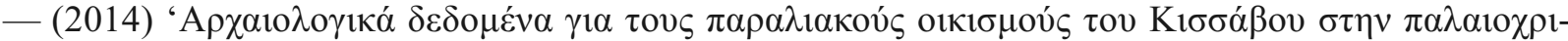

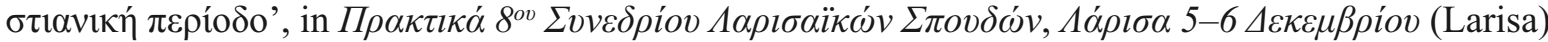
$61-72$

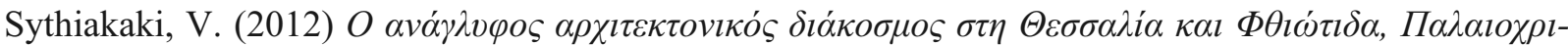

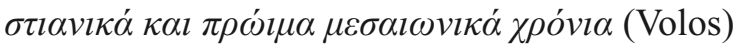

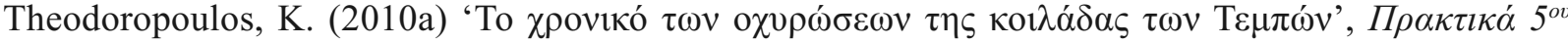

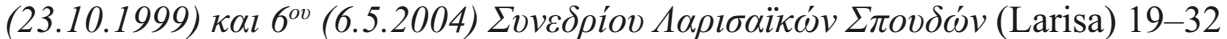

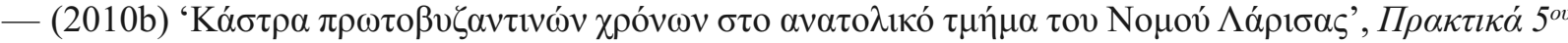

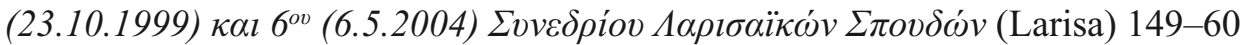

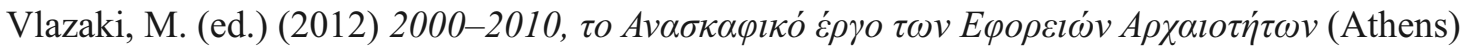

